\title{
Interest Rate Pass-Through in Colombia: a Micro-Banking Perspective*
}

\author{
Rocío BETANCOURT \\ Banco de la República, Colombia \\ HERNANDO VARGAS \\ Banco de la República, Colombia \\ NORBERTO RODRÍGUEZ \\ Banco de la República, Colombia
}

\begin{abstract}
Banks and other credit institutions are key players in the transmission of monetary policy, especially when the responses of deposit and loan interest rates to shifts in policy rates are among the most important channels. This pass-through depends on the conditions prevailing in the loan and deposit markets, which are, in turn, affected by macroeconomic factors. Hence, when setting their policy, monetary authorities must take into account those conditions and the behavior of banks. This paper shows this point using a micro-banking model and presents supporting empirical evidence based on monthly data for Colombia between 1999 and 2006.
\end{abstract}

\section{JEL: G21, E43, E52}

Keywords: Monetary Transmission Mechanisms, Interest Rate Pass-Through, Banking.

\section{INTRODUCTION}

In some economies, banks and other financial institutions play a key role in the expenditure decisions of firms and households. They are among the most important alternatives of funding and means of saving. As such, banks and bank behavior are critical components of the transmission mechanism of monetary policy. In particular, the interest rate channel of monetary policy, which operates

* The opinions expressed in this paper are those of the authors and do not represent the views of the Banco de la República or of its Board of Directors. We thank the anonymous referees for helpful comments.

Email: ybetanga@banrep.gov.co. 
when banks transmit the changes in the monetary policy rate to their customers' interest rates, depends on the banks' reaction to different shocks and to the state of the economy. Hence, when setting their policy, monetary authorities should take into account banks' behavior under different economic conditions.

This paper illustrates the idea that the response of market interest rates to changes in the policy interest rate depends on the reaction of banks and financial markets to different shocks hitting the economy. For that purpose, we develop a theoretical microeconomic model of the banking firm and the credit and deposits markets in which the effects of monetary policy and other macroeconomic variables are included. We also present some supporting evidence for the Colombian economy. The results from the empirical analysis (Error Correction -here after EC- and VARX models) highlight the importance of macroeconomic variables other than the policy interest rate in the transmission mechanism of monetary policy to the market interest rates.

Specifically, according to the EC models, a shock to the policy rate is transmitted to the bank deposit interest rates to a large extent. However, the estimated pass-through is incomplete in the short run for two measures of the deposit rates. For one of those measures, the estimated pass-through is also incomplete in the long run. At the same time, changes in the EMBI index (JP Morgan Emerging Markets Bond Index) have significant and large effects on the deposit rates, and other variables like industrial production, the depreciation of the currency and the LIBO rate have significant effects on the short-term dynamics of market rates.

The results from the VARX models show that the long run pass-through is complete for the two measures of the deposit interest rates used. In addition, the cumulative impulse response functions and the Granger Causality tests obtained from the VARX estimation indicate that other variables, especially the EMBI, have important effects in the determination of market interest rates.

The paper is organized as follows. A brief review of the literature is given in section 2. The theoretical model of the banking firm and the financial markets equilibrium is developed in section 3. Finally, some supporting evidence for the Colombian case is presented in section 4 and we conclude in section 5 .

\section{Literature REVIEW}

\subsection{The Banking Sector and Interest Rate Pass-Through}

The literature has identified different transmission mechanisms of monetary policy such as the interest rate channel, the credit channel and the exchange rate channel among others ${ }^{1}$. The importance of the banking sector in the transmission of interest rates has been recently recognized in the literature on the interest rate

\footnotetext{
${ }^{1}$ See Loayza and Schmidt-Hebbel (2002) for an overview about the transmission mechanisms.
} 
channel $^{2}$. At the same time, the credit channel has focused on the agency problems that arise between financial institutions, particularly banks, and the agents to which they lend (e.g. Bernanke and Gertler, 1995) ${ }^{3}$. Therefore, the credit channel is now considered as a set of factors that amplify and propagate the effects of the interest rate channel through their impact on lending rates and other interest rate spreads.

The banking sector has been incorporated in this literature, focusing mainly on the financial structure and information asymmetries ${ }^{4}$. These two elements clearly influence the behavior of banks and help explain why lending and deposit rates may show a limited response to changes in the monetary policy rate. From Hannan and Berger (1991) and Cottarelli and Kourelis (1994), the stickiness of bank lending interest rates after a change in the money market rates has been explained by different features of the financial structure. Empirical studies, like Berstein and Fuentes (2003) and Kot (2004) have found some degree of rigidity of interest rates in the short run and higher long-run interest rate pass-through coefficients. The degree of competition in the banking sector, the size of the bank, the types of customers and the loan risk level, among other financial features, have been found as the main determinants of interest rate flexibility ${ }^{5}$.

Furthermore, depending on the country and also on the maturity of the interest rates, they may respond less than one-for-one to policy rates, so that the pass-through is incomplete at least in the short run (e.g. De Bondt, 2005). The macroeconomic implications of an incomplete long-run pass-through from policy to bank interest rates are analyzed by Kwapil and Scharler (2005), who find that, under these conditions, the Taylor Principle can be insufficient for equilibrium determinacy 6 .

On a wider perspective, financial structure may influence interest rate pass-through by affecting the response of the financial markets to macroeconomic conditions. In particular, a macroeconomic shock may impact market interest rates directly and in addition to the response of the policy rate to the shock. In this sense, not only market rates may react with a delay to movements in policy rates, but also they may react more, less, or simply not react at all in the short run. As a result,

\footnotetext{
2 The importance of the banking sector in the interest rate pass-through is theoretically studied by Hannan and Berger (1991) and empirically assessed by Cottarelli and Kourelis (1994). For an overview of the banking industry and monetary policy literature see Ahumada and Fuentes (2004).

${ }^{3}$ In contrast to the classical monetarist view that emphasizes the role of narrow and broad monetary aggregates in determining prices.

${ }^{4}$ Cottarelli and Kourelis (1994) consider the financial structure as a term that broadly includes different features such as the degree of development of financial markets, the degree of competition within the banking system, the existence of constraints on capital movements and the ownership structure of the financial intermediaries.

5 According to Cottarelli and Kourelis (1994) interest rate stickiness means that in the presence of a change of money market rates, bank rates change by a smaller amount in the short run (short-run stickiness) and possibly also in the long run (long-run stickiness).

6 This principle states that nominal interest rates have to respond at least one-for-one to changes in the expected inflation rate to guarantee a stable and unique equilibrium.
} 
the estimation of interest rate pass-through must control for the direct impact of other macro variables on market rates. This is the theme of our paper.

\subsection{Interest Rate Pass-Through in Colombia}

Studies for Colombia have found that, although there is a long-term relationship between policy and bank interest rates, interest rate pass-through is incomplete. Julio (2001) finds a stable long-term relationship between the interest rates in Colombia using cointegration for two periods, before and after the removal of the exchange rate band. Huertas et al. (2005) use descriptive statistics $^{7}$ to estimate that a $1 \%$ change in the monetary policy rate implies a change of $0.26 \%$ in the 90 -day CDs interest rate in the short-run and a change of $0.6 \%$ in the long run $^{8}$. Melo et al. (2006) using a multivariate VARX-GARCH model find a response of 38 basic points (b.p.) for the interbank interest rate and of 7 b.p. for the 90-day CDs rate to a change of 100 b.p. in the policy rate, during the period January 2001-September 2005.

Additionally, some of these studies have also documented the importance of the banking sector in Colombia and have suggested its significance in the transmission of interest rates. Huertas et al. (2005) show that bank credit was the most important source of funds for firms between 2000 and $2004^{9}$. However, they indicate that the rather low transmission of the monetary policy interest rate to market interest rates can be explained by a loss in the effectiveness of the credit channel. They attribute this to the increase of banks' holdings of Government bonds as an alternative to loans ${ }^{10}$, and to the declining share of bank loans as a source of funds for firms during this period ${ }^{11}$.

Given the documented importance of the banking sector in the transmission mechanism in Colombia, a complete analysis of interest rate pass-through must involve bank behavior and the equilibrium in the loan and deposit markets, and its estimation must control for movements in other macroeconomic variables apart from the policy interest rate. Here we take into account these arguments to estimate the short run and long run interest rate pass-through for the Colombian case.

\footnotetext{
7 The authors also use VAR models in differences in order to see the impact of the interbank interest rate on the 90-day CDs interest rate (DTF).

8 The short run corresponds to one week and the long-run elasticity was calculated as an average of the change in the interest rates between movements in policy rates during the period from March 2001 to December 2004.

9 The authors analyze a sample of 3.585 financial-statement-reporting firms.

${ }^{10}$ According to the authors the proportion of the private credit on the banks' total assets was $85 \%$ in 1994 and 65\% in 2004, while the banks' public investments as a proportion of the total assets increased from $7 \%$ to $27 \%$ during the same period.

${ }^{11}$ This is in agreement with the results of Zamudio and Martinez (2006), who find that firms decreased their debt with the financial sector in 2005 and internal savings were their main source of funds (52\% in contrast to $48 \%$ of external resources).
} 


\section{A Micro-Banking Model}

Recently, microeconomic models of banks' behavior have been used to explain the role of financial structure in the transmission of interest rates. Berstein and Fuentes (2003) present a Monti-Klein model to explain the long run behavior of the banks under imperfect competition, taking into account the existence of credit risk. By using disaggregated data for different banks, they find that banks' characteristics can influence the degree of delay in the market interest rate response to changes in the policy rate. Kot (2004) uses a similar microeconomic approach to assess the impact of the degree of competition in the credit market on the interest rates pass-through. Amaya (2005) find empirical evidence for Colombia of the importance of banks' characteristics and inflation as long-run drivers of the market interest rates in a competitive setting.

Following this strand of the literature, a partial equilibrium model is used in order to explain the transmission of interest rates under a perfectly competitive structure of the banking sector. From this model, two main results are obtained. First, some macroeconomic variables apart from the policy rate are important determinants of equilibrium market interest rates. Second, the relationship between policy and market interest rates may not be "one-for-one" and possibly not even linear.

\subsection{Assumptions}

Following Freixas and Rochet (1997) we consider a micro-banking model which allows for the existence of liquidity risk. This risk appears when there is an insufficient amount of reserves to serve the total amount of withdrawals made by the depositors.

We assume that the level of reserves $(R)$ chosen by banks and the amount of withdrawals $(X)$ made by agents depend on the level of deposits, so $R=r D$ and $X=\tilde{x} D$ where $0 \leq r \leq 1$ and $\tilde{x} \in[0,1]$. This implies that the maximum amount of withdrawals is equal to the total amount of deposits ${ }^{12}$ and that when $\tilde{x} \in(r, 1]$, banks have to borrow the shortfall from the Central Bank, incurring a cost $I(D, r)=r_{p} D \mathrm{E}[\max (0, \tilde{x}-r)]$, where $r_{p}$ is the policy interest rate. Further, we assume that the proportion of withdrawals follows a uniform distribution between 0 and 1 , so that $\tilde{x} \sim U(0,1)$ and $I(D, r)=\frac{r_{p} D}{2}(1-r)^{2}$.

Additionally, to understand how credit risk affects the competitive pricing of loans, we introduce a simple approach in which banks can recover only a fraction $\delta$ of the loans granted $(L)$. The recovered proportion depends positively on the economic conditions of agents, measured by the income $(Y)^{13}$, and negatively

\footnotetext{
12 In contrast to Freixas and Rochet (1997), there are no additional deposits.

13 If firms and households have good economic conditions, they can repay their loans with higher probability.
} 
on the loan interest rate $\left(r_{L}\right)^{14}$. Therefore, only a proportion $\delta\left(Y, r_{L}\right)$ of the loans are paid back and only on this portion, agents pay interest. Thus, each bank has a net revenue given by $r_{L} \delta\left(Y, r_{L}\right) L-\left(1-\delta\left(Y, r_{L}\right)\right) L$.

Since banking activity is modeled as the production of deposit and loan services, the technology is represented by a cost function $C(D, L)$ that can be interpreted as the cost of managing a volume $D$ of deposits and a volume $L$ of loans. The cost function is the same for all banks ${ }^{15}$. Moreover, it can be assumed without loss of generality that costs are separable (cross-effects are zero), which means that we don't take into account the existence of economies of scope in the joint production of loans and deposits.

Finally, we incorporate banks' holdings of government domestic bonds as an important decision variable, given that they have increased rapidly in Colombia since 2000. Thus, banks can invest in this riskless but illiquid asset (T), with return $r_{T}$.

\subsection{The Bank's Problem}

Assuming a given banking technology, we examine the behavior of this sector under a perfectly competitive structure, where there are $N$ risk-neutral banks that are price takers ${ }^{16}$. Each bank chooses the volumes of deposits $(D)$, loans $(L)$, reserves $(R)$ and government securities $(T)$ that maximize profits subject to the balance sheet constraint:

$$
\begin{aligned}
& \operatorname{Max}_{D, L, T, R} \pi=r_{L} \delta(.) L+r_{T} T-r_{D} D-(1-\delta(.)) L-I(D, r)-C(D, L) \\
& \text { s.t. }\left\{\begin{array}{l}
R=D-L-T \\
R=r D \\
I(D, r)=\frac{r_{p} D}{2}(1-r)^{2} \\
0 \leq \delta \leq 1 \\
0 \leq r \leq 1
\end{array}\right.
\end{aligned}
$$

\footnotetext{
${ }^{14}$ This can be interpreted in two ways. First, an increase in the loan interest rate implies a higher cost of resources for agents, causing a higher probability of default. The second interpretation follows Stiglitz and Weiss (1981) credit rationing argument, according to which an increase in the loan interest rate changes the risk of the population, either because agents take more risky projects or because less risky firms drop out of the market.

15 This function is supposed to satisfy the usual conditions of convexity and regularity.

16 They take as given the rate of loans, $r_{L}$, the rate of deposits, $r_{D}$, the return on government securities, $r_{T}$, and the policy rate, $r_{p}$.
} 
This problem can be rewritten as follows:

(2) $\operatorname{Max} \pi_{D, T, r}=r_{L} \delta().[(1-r) D-T]+r_{T} T-r_{D} D-(1-\delta()).[(1-r) D-T][]$

$$
-\frac{r_{p} D}{2}(1-r)^{2}-C(D,(1-r) D-T)
$$

s.t. $\left\{\begin{array}{l}0 \leq \delta \leq 1 \\ 0 \leq r \leq 1\end{array}\right.$

where bank's profits are the revenues on assets (loans and government securities ${ }^{17}$ ) minus the interest paid on the liabilities (deposits), the costs from credit and liquidity risks, and the operational costs.

Profit maximizing behavior for each bank is characterized by the following first order conditions:

$$
r_{D}=(1-r)\left[\delta(.)\left(1+r_{L}\right)-1-\frac{r_{p}}{2}(1-r)-C_{L}^{\prime}\right]-C_{D}^{\prime}
$$

$$
r_{T}=\delta(.)\left(1+r_{L}\right)-1-C_{L}^{\prime}
$$

$$
r=1-\frac{\delta(.)\left(1+r_{L}\right)-1-C_{L}^{\prime}}{r_{p}}
$$

From equations (3) and (5) we obtain:

$$
r_{D}=\frac{\left[\delta(.)\left(1+r_{L}\right)-C_{L}^{\prime}-1\right]^{2}}{2 r_{p}}-C_{D}^{\prime}
$$

where $C_{L}^{\prime}$ and $C_{D}^{\prime}$ are the operational marginal costs of loans and deposits, respectively. As in Freixas and Rochet (1997) and to simplify our analysis, these costs are assumed to be constant, so $C_{L}^{\prime}=\gamma_{L}$ and $C_{D}^{\prime}=\gamma_{D}$.

${ }^{17}$ We assume that reserves do not have any return because we do not take into account the interbank market. It means that banks keep in cash their reserves and that they borrow only from the Central Bank at a cost $r_{p}$. 
Equation (3) implies that a competitive bank chooses the optimal amount of deposits in such a way that the marginal net revenue (taking into account the credit risk $)^{18},(1-r)\left[\delta().\left(1+r_{L}\right)-1\right]-r_{D}$, must equal the marginal cost, which corresponds to the illiquidity and the operational costs ${ }^{19},(1-r)\left[\frac{r_{p}}{2}(1-r)+\gamma_{L}\right]+\gamma_{D}$.

Equation (4) states that the marginal revenue on government bonds, $r_{T}$, must equal their marginal opportunity cost (of not lending to private agents, taking into account the credit risk), $\delta().\left(1+r_{L}\right)-1-\gamma_{L}$. Finally, from equation (5), the optimal level of reserves depends on their opportunity cost (of not lending these resources to private agents), relative to the savings from not having to borrow them from the Central Bank, $\frac{\delta(.)\left(1+r_{L}\right)-1-\gamma_{L}}{r_{p}}$.

\subsection{Equilibrium in the Deposit and Credit Markets}

In order to close the model and find the equilibrium market rates, we put together the balance sheets of the banks and the equilibrium conditions for the Deposit and Credit markets. The competitive equilibrium is characterized then by equations (3)-(5) and the following conditions:

$$
\begin{aligned}
& D=D^{s}\left(r_{D}, r_{D}^{*}, r_{T}, Y\right) \\
& L=L^{d}\left(r_{L}, r_{L}^{*}, Y\right) \\
& T=T^{s}-T_{-b}^{d}\left(r_{D}, r_{D}^{*}, r_{T}, Y\right) \\
& D(1-r)=L+T
\end{aligned}
$$

where:

- $\quad D^{s}\left(r_{D}, r_{D}^{*}, r_{T}, Y\right)$ is the total supply of deposits by non-financial agents, which depends positively on the domestic deposit interest rate and income, and negatively on the foreign deposit interest rate and the return on government securities. It is assumed that these two types of assets are imperfect substitutes of domestic deposits.

- $\quad L^{d}\left(r_{L}, r_{L}^{*}, Y\right)$ is the loan demand by non-financial agents in the economy, that depends negatively on the loan domestic interest rate and positively on the agents' level of income. It also depends positively on foreign loans

\footnotetext{
18 This net income becomes from the possibility of lend a proportion $(1-r)$ of the deposits and pay interest on the total amount of deposits. It is necessary to take into account that there is a credit risk that not allows recovering all the loans granted and only a proportion of them pay interest.

19 The illiquidity and the loan management costs depend on the proportion of deposits granted in loans.
} 
interest rates, which are assumed to be imperfect substitutes of domestic loans.

- $\quad T^{s}$ is the exogenous supply of securities by the government and $T_{-b}^{d}\left(r_{D}, r_{D}^{*}, r_{T}, Y\right)$ is the demand of these securities by other agents in the economy different from banks. It depends positively on the income and the own return, and negatively on the interest rate paid by domestic and foreign deposits, considered as imperfect substitutes of these securities. Hence, in equilibrium:

$$
L^{d}\left(r_{L}, r_{L}^{*}, Y\right)=(1-r) D^{s}\left(r_{D}, r_{D}^{*}, r_{T}, Y\right)-T^{S}+T_{-b}^{d}\left(r_{D}, r_{D}^{*}, r_{T}, Y\right)
$$

The equilibrium deposit and loan interest rates are derived from equations (3), (4), (5) and (11), as implicit functions of the exogenous variables $r_{L}=r_{L}\left(r_{p}, r_{L}^{*}, r_{D}^{*}, T^{S}, Y, \gamma_{L}, \gamma_{D}\right)$ and $r_{D}=r_{D}\left(r_{p}, r_{L}^{*}, r_{D}^{*}, T^{S}, Y, \gamma_{L}, \gamma_{D}\right)$. These functions are potentially non-linear because they depend on the functional forms of the deposit supply and loan demand ${ }^{20}$.

\subsection{The Results}

The comparative statics analysis of equations (3)-(5) and (11) allows us to appreciate the effects of shocks to the exogenous variables on deposit and loan interest rates (see Appendix A for the details).

Result 1: The effect of a shift in the monetary policy interest rate, $r_{p}$, on the equilibrium loan interest rate is positive. The effect of the same shift on the deposit interest rate is ambiguous.

An increase in the policy interest rate makes the liquidity shortage more costly for banks. This has two implications. On the one hand, banks have more incentives to keep a higher level of reserves, implying a decrease in banks' loan supply or an increase in deposit demand. Hence, there is an upward pressure on loan and deposit interest rates. On the other hand, since the cost of illiquidity depends on the amount of deposits, the rise in policy rates makes deposits more expensive and reduces banks' demand for them. This pushes deposit rates down.

Result 2: A change in the foreign interest rates or the expectations of depreciation has a positive effect on equilibrium loan and deposit interest rates.

If the foreign interest rates or the expectations of depreciation rise, agents in the domestic economy perceive a higher cost of borrowing abroad, increasing their demand for domestic loans. Thus, domestic loan interest rates increase. The higher demand for loans makes banks raise their deposit demand at the same time that agents reduce their supply of deposits because foreign deposits are more attractive. Hence, deposit interest rates also increase.

20 Also, these functions can be non-linear if the withdrawals have a non-uniform probability distribution. 
Result 3: The effect of a change in the income level on the equilibrium loan and deposit interest rates is ambiguous.

An increase in income raises deposit supply and loan demand, implying a decline in the deposit rate and an increase in the loan rate. In order to satisfy the higher demand for loans, banks increase their demand for deposits, pushing deposit interest rates up. Additionally, given that credit risk is reduced by the agents' better conditions (a higher proportion of loans will be recovered), banks have incentives to increase their loan supply inducing a downward pressure on loan rates. As a result, the effect of the shift in income on market rates is ambiguous.

Result 4: An increase in the government securities supply, $T^{s}$, implies a rise in the equilibrium level of loan and deposit interest rates.

An additional supply of government securities competes with loans in banks' portfolios and with deposits in the agents' portfolios. This implies a reduction in the supply of deposits by firms and households, and a drop in the loan supply by commercial banks, increasing interest rates. This effect is reinforced if banks increase their demand for deposits to fund their purchases of government securities.

Notice that, in general, the response of market interest rates to the exogenous shocks may not be linear and could depend on macro variables affecting the elasticities of the loan supply and the demand for deposits. In other words, that response is complex and may depend on the state of the economy. Furthermore, it is possible that a shock to an exogenous variable has an impact on others. For example, an increase in the foreign interest rate may cause movements in the policy rate, the expectations of depreciation and output. Hence, the observed response of market rates to "a" shock may involve a reaction to movements in several variables.

As a corollary, we conclude that there is a possibly complex relationship between policy and market interest rates. We also conclude that interest rate passthrough depends on the state of the economy and that its estimation must control for the presence of other shocks hitting the financial markets.

\section{EMPIRICAL EVIDENCE FOR COLOMBIA}

The literature for Colombia has shown that the importance of substitutes for loans in banks' and firms' balance sheets has increased since 2000 (Huertas et al., 2005 and Zamudio and Martinez, 2006). This change may reflect the adjustment made by agents after the financial crisis and the recession of 1998-1999, and not necessarily a structural change. A reduction of the loan supply might have been due to the higher risk perception of the economy by the financial system after the crisis, and a decrease in loan demand could have occurred because of an explicit policy of leverage reduction by firms and households.

However, bank loans and deposits remain an important component of private sector liabilities and assets. According to the flow of funds accounts, financial debt funded on average $42 \%$ of the households' and small firms' total assets 
during the period 1996-200421. This proportion fell after the recession, but has recovered in recent years (Figure 1). Further, the proportion of small firms' and households' total assets held as deposits in the financial system was on average $42 \%$, for the same period. This evidence suggests that the banking sector plays a relevant role as a provider of funds and as a deposit system for the private sector in the Colombian economy ${ }^{22}$.

FIGURE 1

PRIVATE SECTOR FINANCIAL DEBT AS PERCENTAGE OF TOTAL ASSETS

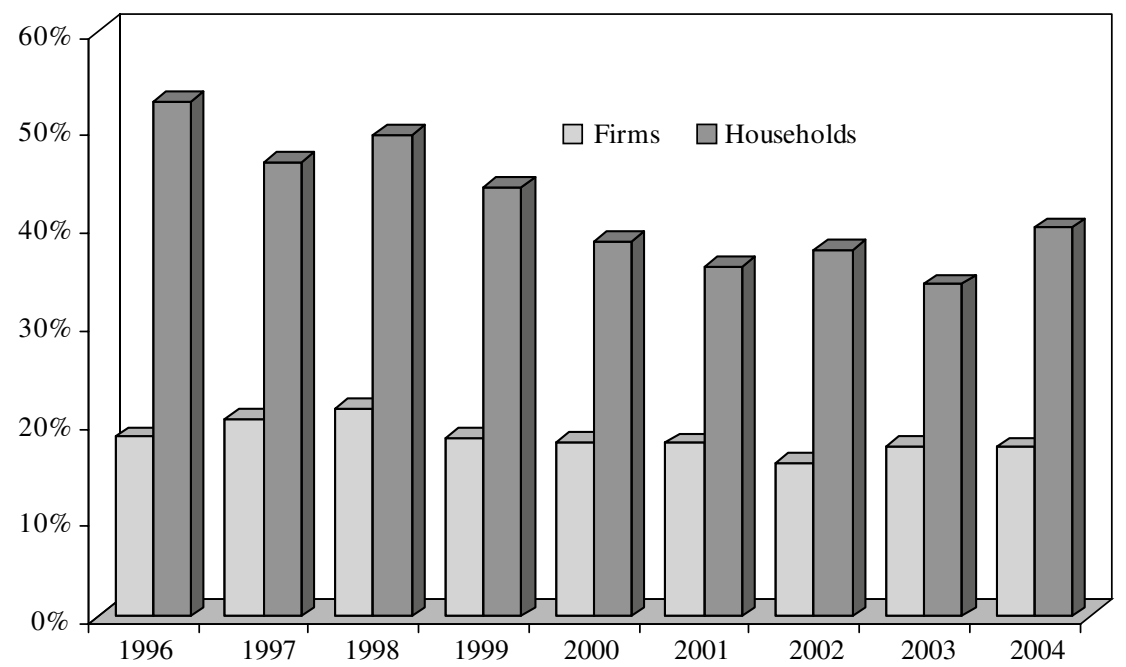

Source: Banco de la República.

For this reason, financial system (loan and deposit) interest rates are important components of the transmission mechanism of monetary policy in Colombia. In this context, the model developed above suggests that the study of the effects of macroeconomic variables on deposit and loan markets is especially relevant. In particular, changes in country risk perceptions, banks' holdings of Government securities or in the loan portfolio quality could explain the dynamics of market and policy rates ${ }^{23}$ and their divergence during the periods January 2000-February 2001 and July 2002-May 2003 in Colombia (Figures 2 and 3).

21 This figure is $18 \%$ for financial-statement-reporting firms in the same period.

22 According to Villar et al. (2005), in 2001 the domestic private credit/GDP ratio (a measure of financial deepening) was $25 \%$ for Colombia, similar to the ratios for Argentina, Perú and Ecuador. This indicator was $65 \%$ for Chile, $97 \%$ for Thailand, $125 \%$ for China and $150 \%$ for Malaysia.

${ }^{23}$ The policy rate corresponds to the interest rate at which the Central Bank gives liquidity to the market by means of an auction, which is called Subasta de Expansión. The market interest rates are the lending and deposit rates. The first one is the average interest rate for all types of loans weighted by their volume. The second one can be measured by the DTF, which corresponds to the weighted average of the interest rates for the 90-day CDs, and by the M3 interest rate, which corresponds to the weighted average of the interest rates for different types of deposits. 
FIGURE 2

NOMINAL INTEREST RATES IN COLOMBIA

a) Interest rates in percentage

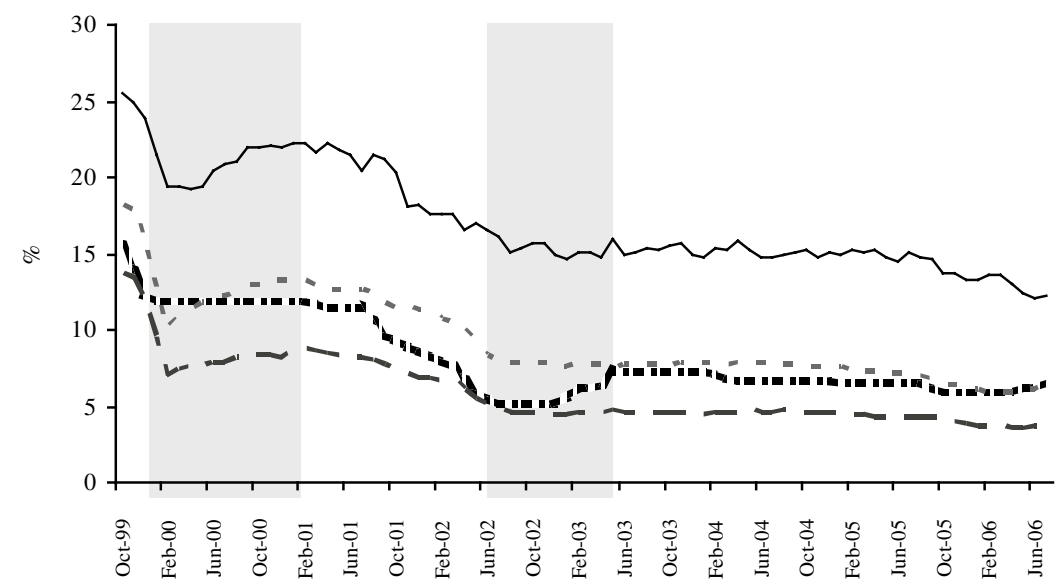

$$
\begin{aligned}
& \text { - m m molicy interest rate L Loan interest rate } \\
& \text { _ } \quad \text { M3 interest rate } \quad \text { - - - . 90-day deposit interest rate (DTF) }
\end{aligned}
$$

Source: Banco de la República.

b) Differential between market and policy interest rates

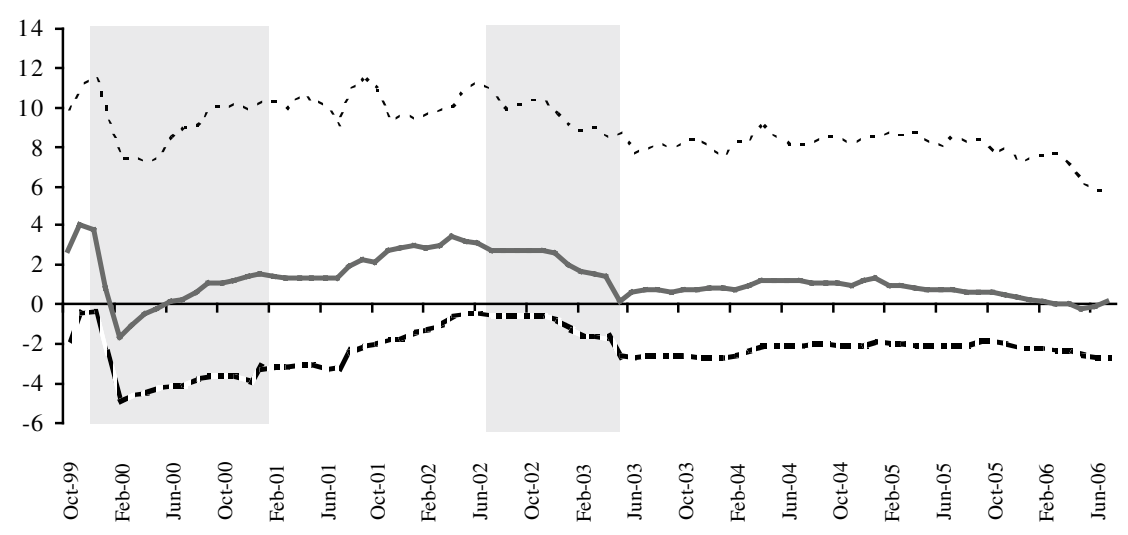

$$
\text { ... . . . - Loan minus policy rate } \longrightarrow \text { DTF minus policy rate }
$$

Source: Banco de la República. 
FIGURE 3

MACROECONOMIC VARIABLES ON DEPOSITS AND LOAN MARKETS

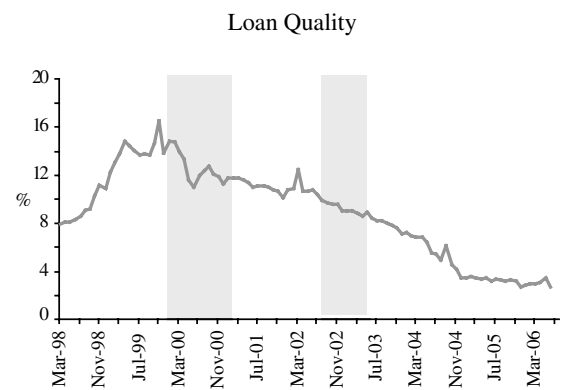

Source: Banco de la República.

Government Securities/Total Financial Sector Assets

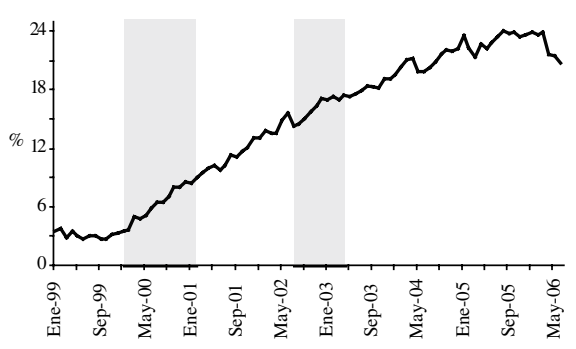

Source: Banco de la República.

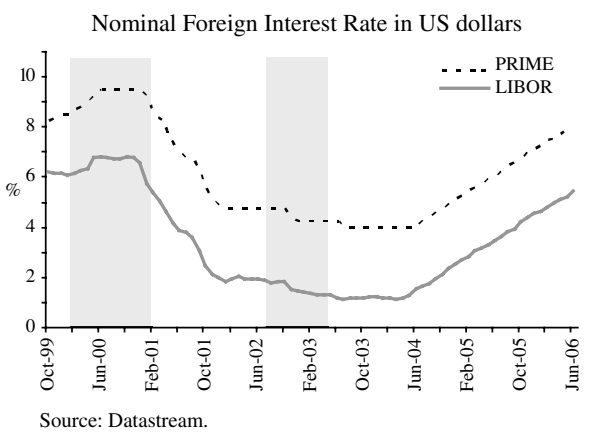

Colombia EMBI and Nominal Depreciation

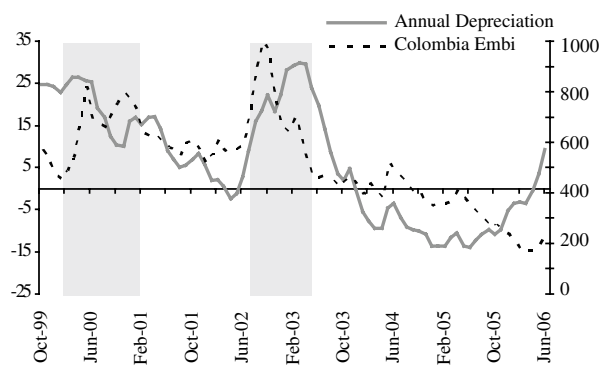

Source: Bloomberg and Banco de la República.

\subsection{Econometric Evidence}

The theoretical model developed previously implies that market interest rates are affected by factors other than the policy rate. Therefore, the estimation of interest rate pass-through must control for movements in other macroeconomic variables, which may impact the loan and deposit markets equilibrium.

Using the Colombian data for the period June 1999-August 2006 we test this hypothesis following two approaches. First, we assume the existence of a long run relationship between market and policy interest rates. Then we estimate uni-equational error correction models for the market rates, in which other macro variables suggested by the theoretical model are included as explanatory variables of the short run dynamics.

In the second approach we acknowledge that some of the macro explanatory variables may be endogenous in a general equilibrium context. Hence, we estimate a VARX, perform Granger causality tests for the market interest rate equation to verify the significance of the macro variables in determining its dynamics, and examine the impulse response functions to check the direction of the market interest rate reaction to different shocks. 


\section{Uni-equational Error Correction Models}

Assuming a long run relationship between market and policy interest rates, we estimate uni-equational error correction models for two different measures of the deposit interest rate, a weighted average of the 90-day CDs interest rates (DTF) and a weighted average of the interest rates for different types of deposits (M3). The short run dynamics is modeled using the EMBI, the foreign interest rate (LIBOR), the industrial production index (as a measure of output) and the nominal depreciation as explanatory variables (For the description of the variables see Appendix C).

Tables 1 and 2, show the estimations of two different models for each measure of the deposit interest rate. The first model takes as explanatory variables the EMBI, the LIBOR and the policy interest rate, which can be assumed to be exogenous in a more general model. The second model also includes the nominal depreciation and the industrial production index (IPI) as exogenous variables, although they can be endogenous in a more general setting. In most cases, variables different from the policy interest rate and the residual of the long run equation ${ }^{24}$ are significant in the error correction equations and the signs are those predicted by the theory, with the notable exception of the foreign interest rate.

The results show that the most important variable in the determination of the deposit interest rate, in terms of the short run effect, is the policy rate. The sum of the policy rate coefficients in the EC equation is 0.92 for the DTF and 0.90 for the M3 interest rate in the first model. However, when the industrial production is introduced in the second model, this variable has the biggest effect on the DTF and the effect of the policy rate is reduced to 0.64. Although, the IPI is not significant for the M3 interest rate the effect of the policy rate decreases to 0.82 in the second model because of the existence of other explanatory variables.

The significance of the estimated coefficients for the macro variables, other than the policy rate, indicates their importance in the determination of the deposit rates. For example, in the first model an increase of 100 basis points (b.p.) in the EMBI produces an increase of 53 b.p. in the DTF and of 30 b.p. in the M3 interest rate, as expected in the theoretical model ${ }^{25}$. Also, an increase of $1 \%$ in the IPI implies a decrease of $1.5 \%$ in the DTF, meaning that the rise in the deposit supply due to a higher agents' income compensates the additional banks' demand for deposits to satisfy a higher demand for loans. On the other hand, although the coefficient of the foreign interest rate is significant, its sign is not as expected, indicating that there is an effect not explained by the theoretical model.

\footnotetext{
24 This residual is obtained from the estimation of the long run relationship between the policy and the deposit interest rate.

${ }^{25}$ However, when the depreciation and the industrial production index are introduced in the second model the effect of the EMBI is reduced to 9 b.p. on the DTF and to 14 b.p. on the M3 rate.
} 
TABLE 1

UNI-EQUATIONAL ERROR CORRECTION MODELS FOR CHANGES IN THE 90-DAY DEPOSIT INTEREST RATE

\begin{tabular}{|c|c|c|}
\hline & Model 1* & Model $2 * *$ \\
\hline CONSTANT & $\begin{array}{c}0.012486 \\
(0.028915)\end{array}$ & $\begin{array}{c}-0.004822 \\
(0.035653)\end{array}$ \\
\hline RESIDUAL(-1) & $\begin{array}{c}-0.090749) \\
(0.032698\end{array}$ & $\begin{array}{c}-0.113041 \\
(0.039219)\end{array}$ \\
\hline$\Delta \mathrm{DTF}(-1)$ & $\begin{array}{c}0.353508 \\
(0.050620)\end{array}$ & $\begin{array}{c}0.373285 \\
(0.065021)\end{array}$ \\
\hline$\Delta \mathrm{DTF}(-3)$ & $\begin{array}{c}-0.337037 \\
(0.068764)\end{array}$ & \\
\hline$\Delta \mathrm{DTF}(-5)$ & $\begin{array}{c}0.217546 \\
(0.064727)\end{array}$ & \\
\hline$\Delta \mathrm{DTF}(-6)$ & $\begin{array}{c}-0.216093 \\
(0.055857)\end{array}$ & \\
\hline$\Delta$ POLICY $(-1)$ & $\begin{array}{c}0.446948 \\
(0.107361)\end{array}$ & $\begin{array}{c}0.640457 \\
(0.126274)\end{array}$ \\
\hline$\triangle \mathrm{POLICY}(-5)$ & $\begin{array}{c}0.468927 \\
(0.111004)\end{array}$ & \\
\hline$\Delta \mathrm{EMBI}(-1)$ & $\begin{array}{c}0.161678 \\
(0.046328)\end{array}$ & $\begin{array}{c}0.094241 \\
(0.057953)\end{array}$ \\
\hline$\Delta \mathrm{EMBI}(-2)$ & $\begin{array}{c}0.164808 \\
(0.050896)\end{array}$ & \\
\hline$\Delta \mathrm{EMBI}(-4)$ & $\begin{array}{c}0.200096 \\
(0.047136)\end{array}$ & \\
\hline$\Delta \operatorname{LIBOR}(-3)$ & $\begin{array}{c}-0.449696 \\
(0.121258)\end{array}$ & $\begin{array}{c}-0.356040 \\
(0.156003)\end{array}$ \\
\hline$\triangle$ DEPRECIATION(-2) & & $\begin{array}{c}0.005335 \\
(0.002612)\end{array}$ \\
\hline$\Delta \mathrm{IPI}(-5)$ & & $\begin{array}{r}-1.514 \\
(0.782946)\end{array}$ \\
\hline \multicolumn{3}{|l|}{$\Delta \operatorname{ITES}(-4)$} \\
\hline R-squared & 0.854 & 0.745 \\
\hline Adjusted R-squared & 0.831 & 0.721 \\
\hline S.E. of regression & 0.215 & 0.291 \\
\hline Sum squared resid & 3.147 & 6.248 \\
\hline Log likelihood & 15.949 & -10.805 \\
\hline Durbin-Watson stat & 2.268 & 1.820 \\
\hline Akaike info criterion & -0.099 & 0.459 \\
\hline Schwarz criterion & 0.259 & 0.693 \\
\hline F-statistic & 36.245 & 30.890 \\
\hline
\end{tabular}

Standard error in parenthesis.

* This model does not consider variables which can be endogenous.

Sample 2000:01 - 2006:08. Included observations: 80 after adjustments.

** This model includes other variables that can be endogenous in a more general model.

Sample 1999:11 - 2006: 08. Included observations: 82 after adjustments 
TABLE 2

UNI-EQUATIONAL ERROR CORRECTION MODELS FOR CHANGES IN THE M3 INTEREST RATE

\begin{tabular}{|c|c|c|}
\hline & Model 1* & Model 2** \\
\hline CONSTANT & $\begin{array}{c}0.000408 \\
(0.032130)\end{array}$ & $\begin{array}{c}-0.010530 \\
(0.028778)\end{array}$ \\
\hline RESIDUAL(-1) & $\begin{array}{c}-0.089990 \\
(0.044198)\end{array}$ & $\begin{array}{c}-0.111004 \\
(0.040513)\end{array}$ \\
\hline$\Delta \mathrm{POLICY}(-1)$ & $\begin{array}{l}0.265058 \\
0.116803\end{array}$ & $\begin{array}{c}0.245400 \\
(0.107855)\end{array}$ \\
\hline$\Delta \mathrm{POLICY}(-2)$ & $\begin{array}{c}0.632620 \\
(0.106224)\end{array}$ & $\begin{array}{c}0.578453 \\
(0.098401)\end{array}$ \\
\hline$\Delta \mathrm{EMBI}(-1)$ & $\begin{array}{c}0.131270 \\
(0.049625)\end{array}$ & \\
\hline$\Delta \mathrm{EMBI}(-4)$ & $\begin{array}{c}0.155397 \\
(0.048852)\end{array}$ & $\begin{array}{c}0.141503 \\
(0.050822)\end{array}$ \\
\hline$\Delta \operatorname{LIBOR}(-4)$ & & $\begin{array}{c}-0.418220 \\
(0.120513)\end{array}$ \\
\hline$\triangle$ DEPRECIATION $(-1)$ & & $\begin{array}{c}0.007988 \\
(0.002161)\end{array}$ \\
\hline$\triangle$ DEPRECIATION $(-4)$ & & $\begin{array}{c}0.005280 \\
(0.002380)\end{array}$ \\
\hline R-squared & 0.687 & 0.754 \\
\hline Adjusted R-squared & 0.667 & 0.730 \\
\hline S.E. of regression & 0.253 & 0.228 \\
\hline Sum squared resid & 4.858 & 3.831 \\
\hline Log likelihood & -0.484 & 9.250 \\
\hline Durbin-Watson stat & 1.506 & 1.525 \\
\hline Akaike info criterion & 0.158 & -0.030 \\
\hline Schwarz criterion & 0.334 & 0.204 \\
\hline F-statistic & 33.457 & 32.339 \\
\hline
\end{tabular}

Standard error in parenthesis

* This model does not consider variables which can be endogenous.

Sample 1999:11 - 2006:08. Included observations: 82 after adjustments.

** This model includes other variables that can be endogenous in a more general model.

Sample 1999:11 - 2006: 08. Included observations: 82 after adjustments.

The cumulative impulse-response functions (Figures 4 and 5) show that the long run pass-through from the policy rate to the DTF is complete in both models. However, this pass-through is incomplete for the M3 interest rate (the long run response of the M3 rate to a change in the policy rate is less than one).

The previous results imply that the short run interest rate pass-through to the deposit rate is incomplete but that the long run pass-through is complete at least for the DTF. Moreover, these results show that the introduction of some macroeconomic variables reduces the impact of the policy rate on the deposit rate, given their significance in the explanation of the market interest rates behavior. 
FIGURE 4

ERROR CORRECTION IMPULSE-RESPONSE FUNCTIONS FOR THE DEPOSITS INTEREST RATE (DTF)

Model 1
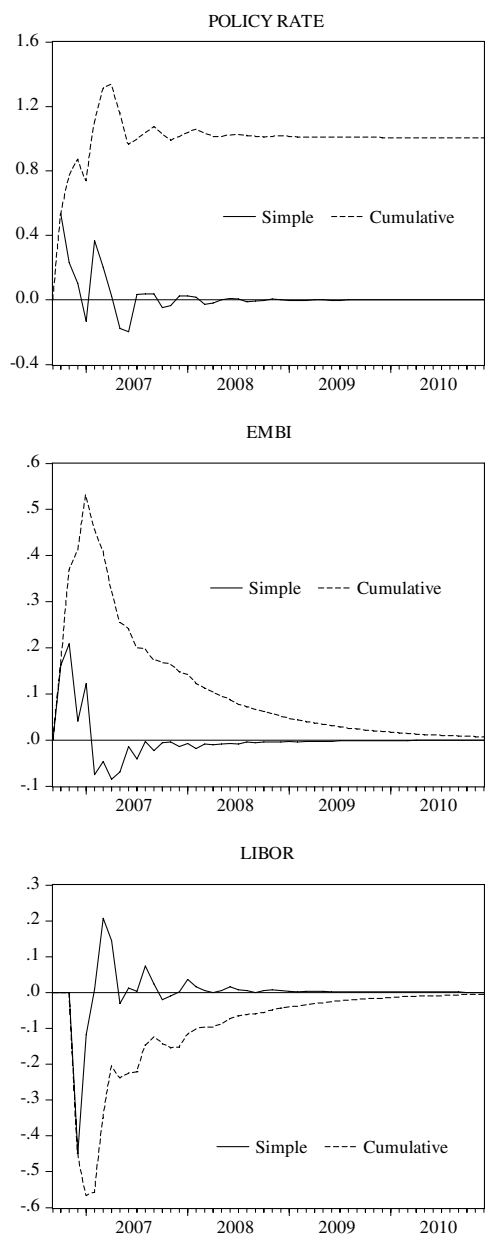

Model 2

POLICY RATE
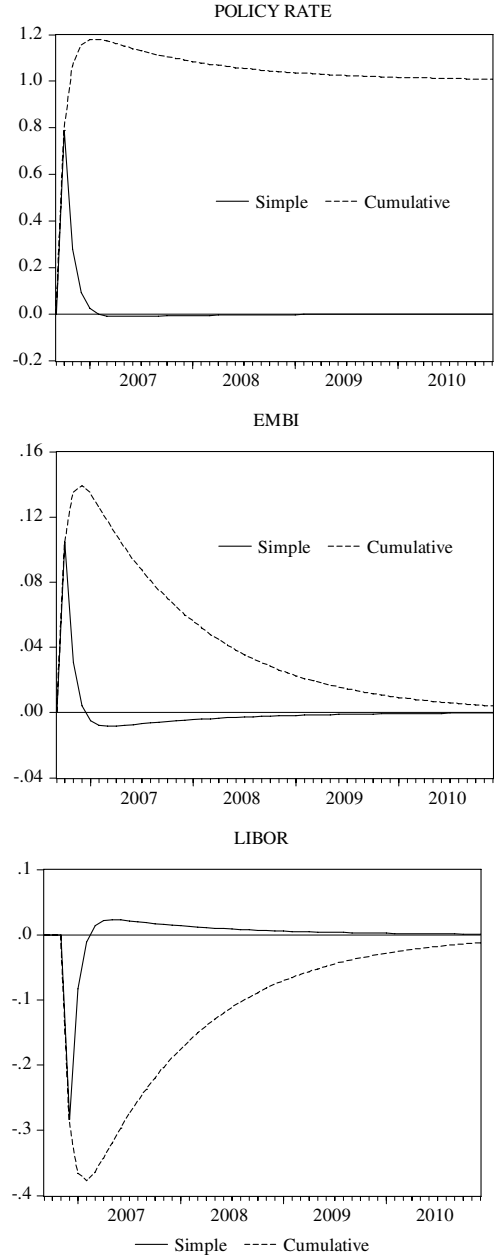

IPI

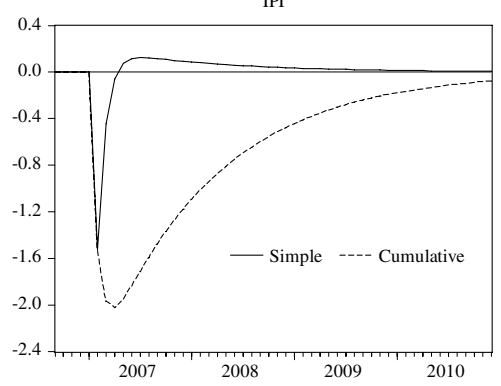


FIGURE 5

ERROR CORRECTION IMPULSE-RESPONSE FUNCTIONS FOR THE M3 INTEREST RATE

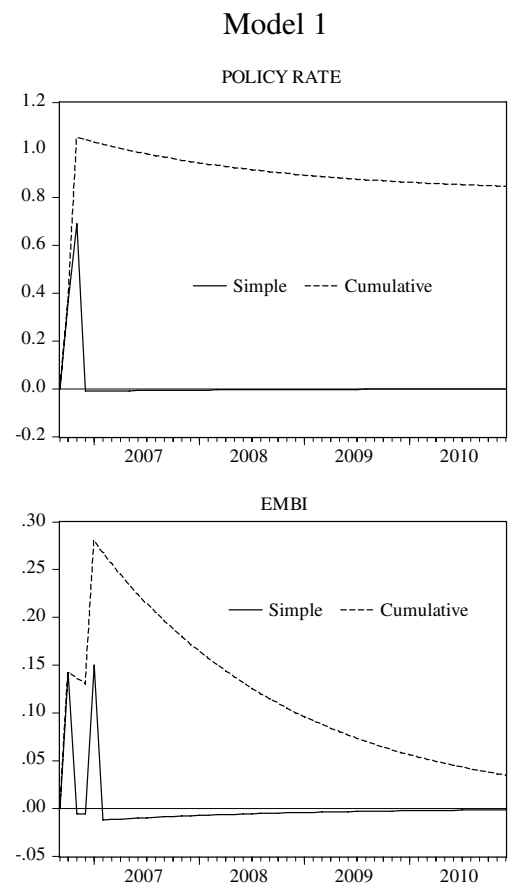

Model 2
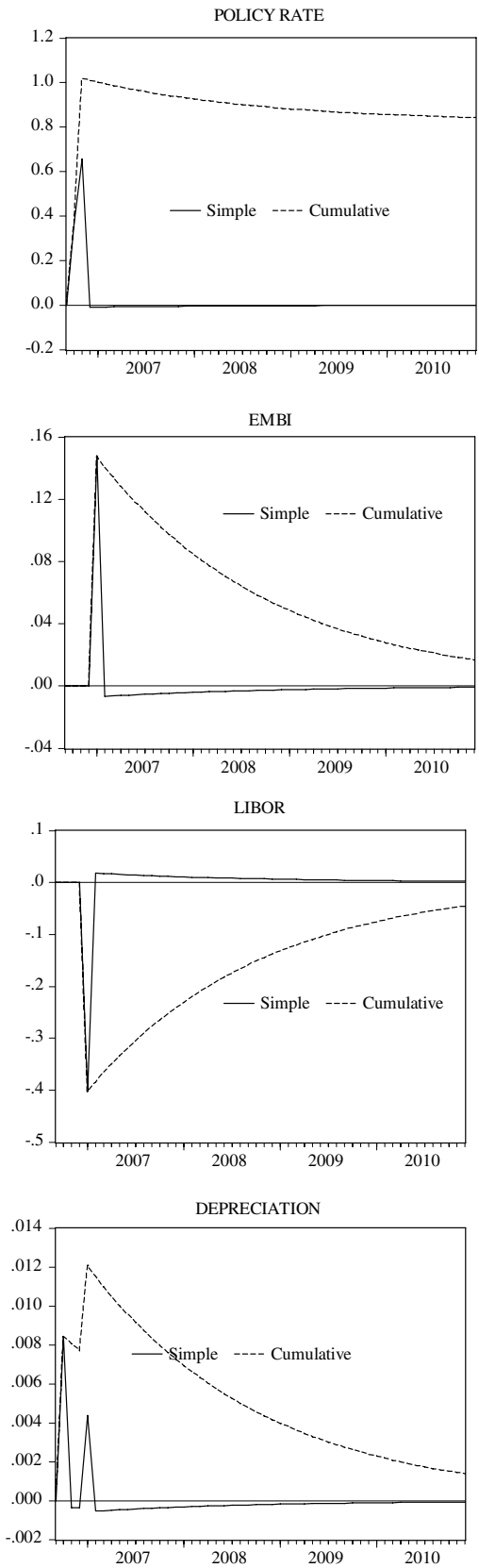


\section{VARX models}

To assess the impact of exogenous shocks on deposit interest rates, one must take into account not only their direct effect, but also the indirect effects that occur through other macro variables that are endogenous in a general equilibrium context, such as the exchange rate and the output. There may be also feed-back from market rates themselves to those macro endogenous variables. To capture the richer dynamics implied by the argument above, we estimate VARX models for a set of variables in first differences. We assume that the EMBI, the foreign interest rates (the LIBOR) and the policy rates are exogenous variables, while deposit rates, inflation, nominal depreciation and our measure of output are treated as endogenous.

In order to verify our hypothesis, we check the significance of variables other than the policy rate in the deposit rate equation by means of Granger causality tests. Tables 3 and 4 show these tests for two specifications of VARX that include the DTF or the M3 interest rate, respectively ${ }^{26}$. According to the equation

TABLE 3

GRANGER CAUSALITY TESTS ON DEPOSITS INTEREST RATE (DTF)

\begin{tabular}{|c|c|c|}
\hline Null Hypothesis & Test-value & Probability \\
\hline$\triangle$ DEPRECIATION not Granger cause DDTF & 31.01 & 0.0001 \\
\hline$\Delta \mathrm{IPI}$ not Granger cause DDTF & 4.70 & 0.5825 \\
\hline$\Delta$ INFLATION not Granger cause DDTF & 7.30 & 0.2938 \\
\hline$\Delta$ EMBI not Granger cause DDTF & 32.42 & 0.0001 \\
\hline$\triangle$ POLICY not Granger cause DDTF & 98.35 & 0.0001 \\
\hline$\Delta$ LIBOR not Granger cause DDTF & 12.77 & 0.0778 \\
\hline
\end{tabular}

Note: The estimated VARX model uses 6 lags for the endogenous and exogenous variables.

TABLE 4

GRANGER CAUSALITY TESTS ON M3 INTEREST RATE

\begin{tabular}{|c|c|c|}
\hline Null Hypothesis & Test-value & Probability \\
\hline $\begin{array}{l}\text { DEPRECIATION not Granger cause DM3 } \\
\end{array}$ & 25.07 & 0.0003 \\
\hline$\Delta$ IPI not Granger cause DM3 & 8.43 & 0.2086 \\
\hline$\triangle$ INFLATION not Granger cause DM3 & 16.70 & 0.0104 \\
\hline$\Delta$ EMBI not Granger cause DM3 & 26.28 & 0.0004 \\
\hline$\Delta$ POLICY not Granger cause DM3 & 99.74 & 0.0001 \\
\hline$\Delta$ LIBOR not Granger cause DM3 & 15.50 & 0.0301 \\
\hline
\end{tabular}

Note: The estimated VARX model uses 6 lags for the endogenous and exogenous variables.

\footnotetext{
${ }^{26}$ There may exist a bias in the estimation because we are not taking into account the long run relationship between market and policy interest rates and other long run relations between the variables included in the VARX. A method that allows to estimate the correct long and short run relationships is a VEC, but the sample is too short to use this technique.
} 
FIGURE 6

\section{CUMULATIVE IMPULSE-RESPONSE FUNCTIONS}

FOR THE DTF EQUATION (IN LOGS)
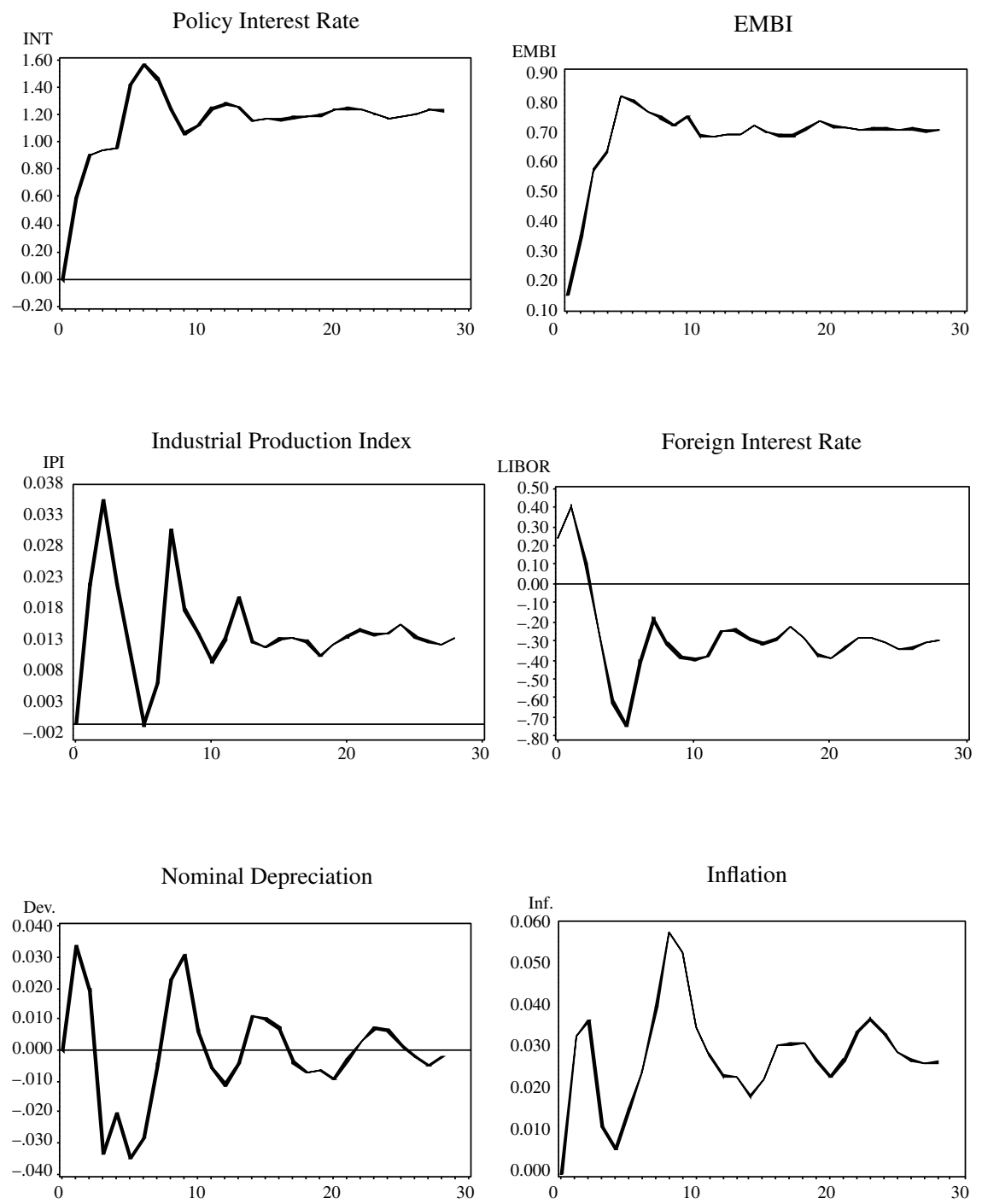
FIGURE 7

CUMULATIVE IMPULSE-RESPONSE FUNCTIONS FOR THE M3 INTEREST RATE EQUATIONS (IN LOGS)
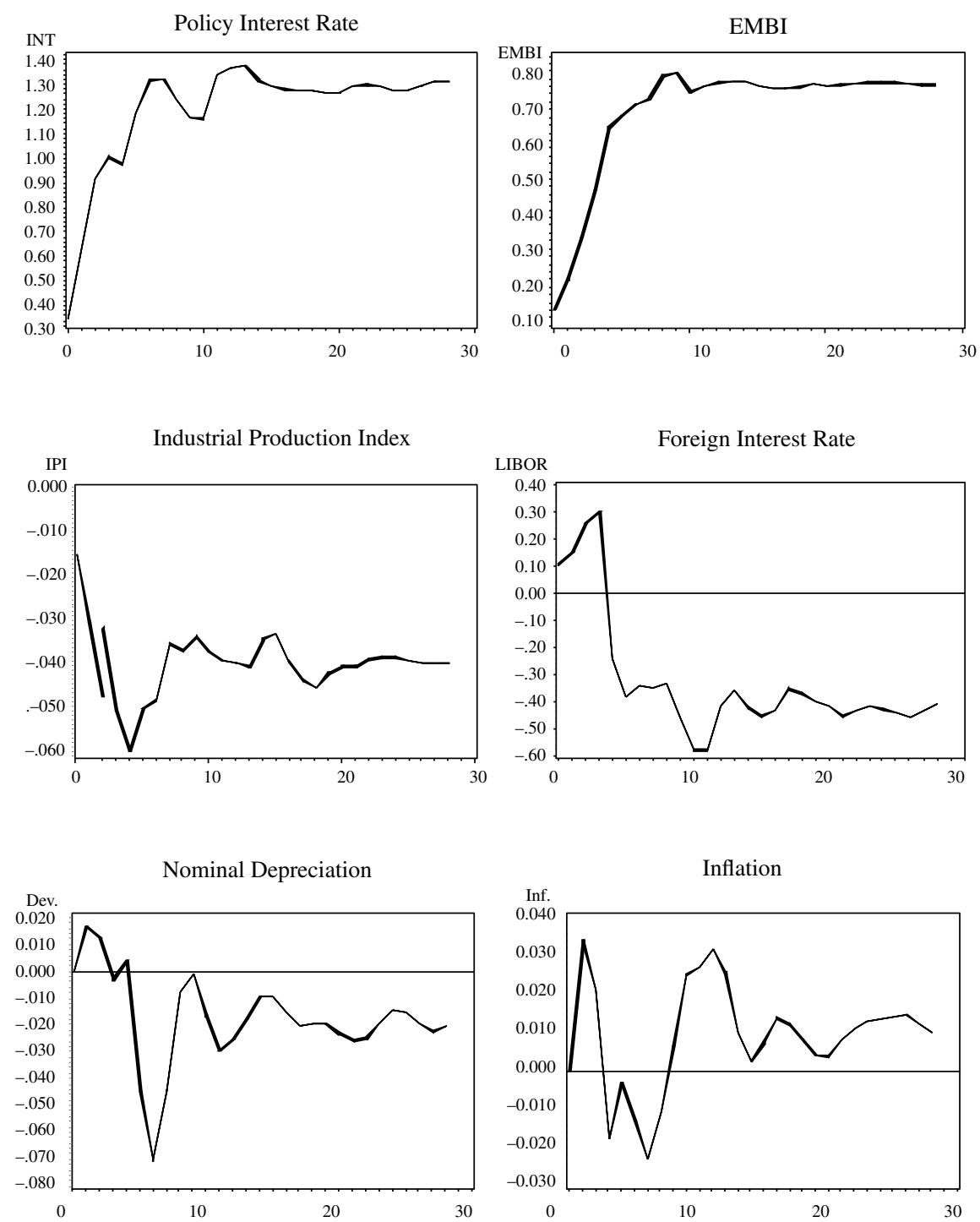
for the DTF, the policy rate, the nominal depreciation, the EMBI and the LIBOR Granger-cause this deposit rate. Also, the policy rate, the inflation, the nominal depreciation, the EMBI and the LIBOR Granger-cause the M3 deposit rate.

From the cumulative impulse-response functions of the VARX models, we examine the impact of some shocks on the two measures of deposit rates (Figures 6 and 7). These functions show a large (higher than one) long run reaction of the market interest rates to policy rate shocks. In this context, this response may be regarded as an appropriate measure of the long-run interest rate pass-through, since most direct and indirect effects are taken into account.

For other shocks, the market interest rates long-run response is in agreement with the theoretical model with the exception of the LIBOR, whose effect is counter-intuitive. In particular, the EMBI has the second highest effect on the deposit rates, after the effect of the policy rate, and the IPI has an ambiguous effect depending on the measure of the deposit rate.

\section{CONCLUSIONS}

In contrast to the standard approach to monetary policy, which considers the banking sector as a passive aggregate, this paper shows the implications of modeling commercial banks as independent entities that optimally react to their environment. Based on a theoretical microeconomic model of the banking firm and the credit and deposits markets, we illustrate the idea that the response of market interest rates to changes in the policy interest rate may be a complex process that depends on the macroeconomic variables comprising the state of the economy.

Given these theoretical results, we argue that the estimation of interest rate pass-through must control for the variables affecting the financial system and the behavior of banks. The results from uni-equational error correction and VARX models for the Colombian data seem to support our hypotheses. These estimations imply that the short run interest rate pass-through to the deposit rate is incomplete while in the long run the transmission of a change in the policy rate is complete. Furthermore, these results show the significance of other macroeconomic variables different from the policy rate on the dynamics of different measures of the deposit interest rate, as suggested by the theoretical model developed above.

Finally, a policy implication follows immediately from the previous arguments and results. The Central Bank's policy decision should take into account the direct effects of macro variables on market rates and consider the complex relationship between policy and market rates. If these factors are empirically relevant, a failure by the Central Bank to include them in its reaction function may increase the risk of missing its targets and/or may introduce excessive volatility to interest rates and output. The importance for the Central Bank of the role of banks and financial markets in the interest rate pass-through can be understood by means of a small-open economy macro model that includes a version of our micro-banking model. This is the matter of future research. 


\section{REFERENCES}

Ahumada, L. and J.R. Fuentes (2004), "Banking Industry and Monetary Policy: An Overview", in Ahumada, L. and J.R. Fuentes, eds., Banking Market Structure and Monetary Policy, Central Bank of Chile.

Amaya, C.A. (2005), "Interest Rate Setting and the Colombian Monetary Transmission Mechanism", Borradores de Economía, Banco de la República Colombia, 352.

Bernanke, B. and A. Blinder (1988), "Credit, Money and Aggregate Demand", American Economic Review, 78 (2): 435-439.

Bernanke, B. and M. Gertler (1995), "Inside the Black Box: The Credit Channel of Monetary Policy Transmission", Journal of Economic Perspectives, 9 (4): 27-48.

Berstein, S. and R. Fuentes (2003), "Is There Lending Rate Stickiness in the Chilean Banking Industry?", Central Bank of Chile Working Papers, 218.

Cottarelli, C. and A. Kourelis (1994), "Financial Structure, Bank Lending Rates, and the Transmission Mechanism of Monetary Policy", IMF Staff Papers, 41 (4): 587-623.

De Bondt, G. (2005), "Interest Rate Pass-Through: Empirical Results for the Euro Area", German Economic Review, 6 (1): 37-78.

Engle, R. and B.S. Yoo (1987), "Forecasting and Testing in Co-integrated Systems", Journal of Econometrics, 35: 143-159.

Freixas X. and J.C. Rochet (1997), Microeconomics of Banking, MIT Press, Cambridge.

Hannan, T. and A. Berger (1991), "The Rigidity of Prices: Evidence from the Banking Industry”, American Economic Review, 81 (4): 938-945.

Huertas, C., M. Jalil, S. Olarte y J. V. Romero (2005), "Algunas Consideraciones sobre el Canal de Crédito y la Transmisión de Tasas de Interés en Colombia", Borradores de Economía, Banco de la República Colombia, 351.

Julio, J.M. (2001), "Relación entre la Tasa de Intervención del Banco de la República y las Tasas del Mercado: Una Exploración Empírica”, Borradores de Economía, Banco de la República Colombia, 188.

Kot, A. (2004), "Is Interest Rate Pass-Through related to Banking Sector Competitiveness?", National Bank of Poland.

Kwapil, C. and J. Scharler (2005), "Interest Rate Pass-Through, Monetary Policy Rules and Macroeconomic Stability", Austrian Central Bank Working Papers, 118.

Loayza, N. and K. Schmidt-Hebbel (2002), "Monetary Policy Functions and Transmission Mechanisms: An Overview", in Loayza N. and K. Schmidt-Hebbel, eds., Monetary Policy: Rules and Transmission Mechanisms, Central Bank of Chile.

Melo, L.F. and O. Becerra (2006), "Una Aproximación a la Dinámica de las Tasas de Interés de Corto Plazo en Colombia a través de Modelos GARCH Multivariados", Borradores de Economía, Banco de la República Colombia, 366.

Mojon, B. (2000), "Financial Structure and the Interest Rate Channel of ECB Monetary Policy”, European Central Bank Working Paper Series, 40.

Sorensen, C.K. and T. Werner (2006), "Bank Interest Rate Pass-Through in the Euro Area: A Cross Country Comparison", European Central Bank Working Paper Series, 580. 
Stiglitz, J. and A. Weiss (1981), "Credit Rationing in Markets with Imperfect Information", American Economic Review, 71 (3): 393-410.

Villar L., D. Salamanca y A. Murcia (2005), "Crédito, Represión Financiera y Flujos de Capitales en Colombia: 1974-2003", Borradores de Economía, Banco de la República Colombia, 322.

Weth, M. (2002), "The Pass-Through from market interest rates to bank lending rates in Germany”, Economic Research Centre of the Deutsche Bundesbank Discussion Paper, 11.

Winker, P. (1999), "Sluggish Adjustment of Interest Rates and Credit Rationing: An Application of Unit Root Testing and Error Correction Modelling", Applied Economics, 31: 267-277.

Zamudio, N. and J. Martinez (2006), "Estructura Financiera de las Empresas y los Hogares 2004-2005”, Mimeo, Banco de la República Colombia. 


\section{APPENDIX A \\ THE MICRO-BANKING MODEL}

A.1. Effect of a marginal shift in the monetary policy interest rate: result:

Differentiating equation (10) with respect to $r_{p}$ yields the following

$$
\frac{d r_{L}}{d r_{p}}=\frac{\frac{\partial r_{D}}{\partial r_{p}}\left[(1-r) \frac{\partial D^{s}}{\partial r_{D}}+\frac{\partial T_{-b}^{d}}{\partial r_{D}}\right]-D^{s}(.) \frac{\partial r}{\partial r_{p}}}{\frac{\partial L^{d}}{\partial r_{L}}-\frac{\partial r_{D}}{\partial r_{L}}\left[(1-r) \frac{\partial D^{s}}{\partial r_{D}}+\frac{\partial T_{-b}^{d}}{\partial r_{D}}\right]-\frac{\partial r_{T}}{\partial r_{L}}\left[(1-r) \frac{\partial D^{s}}{\partial r_{T}}+\frac{\partial T_{-b}^{d}}{\partial r_{T}}\right]+D^{s}(.) \frac{\partial r}{\partial r_{L}}}
$$

where:

$$
\frac{\partial r_{D}}{\partial r_{p}}=-\frac{\left[\delta(.)\left(1+r_{L}\right)-\gamma_{L}-1\right]^{2}}{2 r_{p}^{2}}<0 \text { is the direct impact of the policy rate on }
$$

the deposit rate. This effect is negative because a higher policy rate implies a higher illiquidity cost and, as the withdrawals depend on the amount of deposits, banks will demand deposits only at lower deposit rates.

(ii) $\frac{\partial r_{T}}{\partial r_{L}}=\delta()+.\left(1+r_{L}\right) \frac{\partial \delta}{\partial r_{L}}$ is the impact of the loan interest rate on the government securities return, which is ambiguous because a positive shift in loan interest rates implies an increase in the credit risk, $\frac{\partial \delta}{\partial r_{L}}<0$. However, if the economic conditions are good, the proportion of recovered loans $\delta($. can be sufficiently high to compensate the increasing credit risk, so that, $\frac{\partial r_{T}}{\partial r_{L}}$ will be positive. Intuitively, $\delta()+.\left(1+r_{L}\right) \frac{\partial \delta}{\partial r_{L}}$ is the bank's marginal revenue derived from an increase in $r_{L}$. If it is positive, banks will increase loans, demand less government bonds and the price of the latter will fall ( $r_{T}$ will go up).

(iii) $\frac{\partial r}{\partial r_{L}}=-\frac{\left[\delta(.)+\left(1+r_{L}\right) \frac{\partial \delta}{\partial r_{L}}\right]}{r_{p}}$ is the impact of the loan interest rate on the banks' fraction of reserves It is also ambiguous and depends on credit risk. As before, if the increase in credit risk is smaller than the recovered proportion of loans, this effect is negative. Intuitively, if the bank's revenues increase with the rise in $r_{L}$, banks will lend more and reduce reserves. 
(iv) $\frac{\partial r_{D}}{\partial r_{L}}=\frac{\left(\delta(.)\left(1+r_{L}\right)-\gamma_{L}-1\right)\left(\delta(.)+\left(1+r_{L}\right) \frac{\partial \delta}{\partial r_{L}}\right)}{r_{p}}$ is the impact of loan interest rate on deposit rates. From equation (4), we know that $\left(\delta().\left(1+r_{L}\right)-\gamma_{L}-1\right)$ is positive if there are positive returns on government securities. Additionally, as before, if $\left[\delta()+.\left(1+r_{L}\right) \frac{\partial \delta}{\partial r_{L}}\right]>0$, then $\frac{\partial r_{D}}{\partial r_{L}}>0$. Intuitively, if the bank's revenues increase with the rise in $r_{L}$, they will demand more deposits inducing an upward pressure on $r_{D}$.

(v) $\frac{\partial r}{\partial r_{p}}=\frac{\left(\delta(.)\left(1+r_{L}\right)-\gamma_{L}-1\right)}{r_{p}^{2}}$ is the direct impact of the policy rate on the proportion of reserves, which is positive if $r_{T}>0$. If the policy rate increases, the illiquidity cost goes up, and banks prefer to keep a higher proportion of deposits as reserves.

Finally, $\frac{d r_{L}}{d r_{p}}$ is positive if $\left[\delta()+.\left(1+r_{L}\right) \frac{\partial \delta}{\partial r_{L}}\right]>0$ and the own elasticity on the demand for deposits (demand for government securities) is greater than the cross-elasticity with respect to the return on government securities (the deposit interest rate), namely, $\frac{\partial D^{s}}{\partial r_{D}}>\frac{\partial T_{-b}^{d}}{\partial r_{D}}$ and $\frac{\partial D^{s}}{\partial r_{T}}<\frac{\partial T_{-b}^{d}}{\partial r_{T}}$. Thus we suppose that agents react more to the own returns of each asset than to the return of alternative assets.

The impact of a change in the policy rate on the deposit interest rate depends on the direct effect, which is negative, and the effect through the loan rate, which is positive. Then, the final effect is ambiguous.

\section{A.2. Effect of a marginal change in the foreign interest rates}

Differentiating equation (10) with respect to $r_{L}^{*}$ and $r_{D}^{*}$ yields the following results:

$$
\frac{d r_{L}}{d r_{L}^{*}}=\frac{-\frac{\partial L^{d}}{\partial r_{L}^{*}}}{\frac{\partial L^{d}}{\partial r_{L}}-\frac{\partial r_{D}}{\partial r_{L}}\left[(1-r) \frac{\partial D^{s}}{\partial r_{D}}+\frac{\partial T_{-b}^{d}}{\partial r_{D}}\right]-\frac{\partial r_{T}}{\partial r_{L}}\left[(1-r) \frac{\partial D^{s}}{\partial r_{T}}+\frac{\partial T_{-b}^{d}}{\partial r_{T}}\right]+D^{s}(.) \frac{\partial r}{\partial r_{L}}}
$$




$$
\frac{d r_{L}}{d r_{D}^{*}}=\frac{(1-r) \frac{\partial D^{s}}{\partial r_{D}^{*}}+\frac{\partial T_{-b}^{d}}{\partial r_{D}^{*}}}{\frac{\partial L^{d}}{\partial r_{L}}-\frac{\partial r_{D}}{\partial r_{L}}\left[(1-r) \frac{\partial D^{s}}{\partial r_{D}}+\frac{\partial T_{-b}^{d}}{\partial r_{D}}\right]-\frac{\partial r_{T}}{\partial r_{L}}\left[(1-r) \frac{\partial D^{s}}{\partial r_{T}}+\frac{\partial T_{-b}^{d}}{\partial r_{T}}\right]+D^{s}(.) \frac{\partial r}{\partial r_{L}}}
$$

where $\frac{\partial r_{D}}{\partial r_{L}}, \frac{\partial r_{T}}{\partial r_{L}}$ and $\frac{\partial r}{\partial r_{L}}$ are explained and signed above. The signs of these two expressions depend again on the assumptions about the elasticities. If we assume that the direct elasticities are higher than the cross-elasticities, then the impact of a change in the foreign interest rates is positive on the loan and deposit interest rates.

A.3. Effect of a marginal shift in the level of income: result:

Differentiating equation (10) with respect to $Y$ yields the following

$$
\frac{d r_{L}}{d Y}=\frac{-\frac{\partial L^{d}}{\partial Y}+\frac{\partial r_{D}}{\partial Y}\left[(1-r) \frac{\partial D^{s}}{\partial r_{D}}+\frac{\partial T_{-b}^{d}}{\partial r_{D}}\right]+\frac{\partial r_{T}}{\partial Y}\left[(1-r) \frac{\partial D^{s}}{\partial r_{T}}+\frac{\partial T_{-b}^{d}}{\partial r_{T}}\right]+(1-r) \frac{\partial D^{s}}{\partial Y}-D^{s}(.) \frac{\partial r}{\partial Y}+\frac{\partial T_{-b}^{d}}{\partial Y}}{\frac{\partial L^{d}}{\partial r_{L}}-\frac{\partial r_{D}}{\partial r_{L}}\left[(1-r) \frac{\partial D^{s}}{\partial r_{D}}+\frac{\partial T_{-b}^{d}}{\partial r_{D}}\right]-\frac{\partial r_{T}}{\partial r_{L}}\left[(1-r) \frac{\partial D^{s}}{\partial r_{T}}+\frac{\partial T_{-b}^{d}}{\partial r_{T}}\right]+D^{s}(.) \frac{\partial r}{\partial r_{L}}}
$$

where:

(i) $\frac{\partial r_{D}}{\partial Y}=\frac{\left(\delta(.)\left(1+r_{L}\right)-\gamma_{L}-1\right)\left(1+r_{L}\right)}{r_{p}} \frac{\partial \delta}{\partial Y}$ is positive, because an increase in the level of income improves the credit risk perception of banks and induce them to demand more deposits.

(ii) $\frac{\partial r_{T}}{\partial Y}=\left(1+r_{L}\right) \frac{\partial \delta}{\partial Y}$ is positive because $\frac{\partial \delta}{\partial Y}>0$. An increase in the level of income improves the credit risk perception of banks, induce them to grant more loans and to reduce their demand for government securities. Thus, the return of these bonds must increase (their prices must fall).

(iii) $\frac{\partial r}{\partial Y}=-\frac{\left(1+r_{L}\right)}{r_{p}} \frac{\partial \delta}{\partial Y}$ is negative. If the output increases, credit risk is lower and banks prefer to grant more loans and keep less reserves. 
Although the previous assumptions about the elasticities are made, $\frac{d r_{L}}{d Y}$ is ambiguous, because agents are going to demand more credit, $\frac{\partial L^{d}}{\partial Y}>0$, at the same time that banks grant more loans. The final impact on the deposit rate is also ambiguous, because agents with higher income supply more deposits $\frac{\partial D^{s}}{\partial Y}>0$, while banks increase their demand for deposits.

\section{A.4. Effect of a marginal shift in the government securities supply}

Differentiating equation (10) with respect to $T^{s}$ yields the following results:

$$
\frac{d r_{L}}{d T^{s}}=\frac{-1}{\frac{\partial L^{d}}{\partial r_{L}}-\frac{\partial r_{D}}{\partial r_{L}}\left[(1-r) \frac{\partial D^{s}}{\partial r_{D}}+\frac{\partial T_{-b}^{d}}{\partial r_{D}}\right]-\frac{\partial r_{T}}{\partial r_{L}}\left[(1-r) \frac{\partial D^{s}}{\partial r_{T}}+\frac{\partial T_{-b}^{d}}{\partial r_{T}}\right]+D^{s}(.) \frac{\partial r}{\partial r_{L}}}
$$

where $\frac{\partial r_{D}}{\partial r_{L}}, \frac{\partial r_{T}}{\partial r_{L}}$ and $\frac{\partial r}{\partial r_{L}}$ were explained and signed above. The same assumptions about elasticities imply that $\frac{d r_{L}}{d T^{s}}>0$. If $\frac{\partial r_{D}}{\partial r_{L}}>0$ then $\frac{d r_{D}}{d T^{s}}>0$.

\section{ApPEndix B}

In this appendix we show some econometric results. First we show the results of unit root tests for the interest rates. Then the estimated long-run relationship between policy and market interest rates is shown.

\section{B.1. Unit Root Tests}

We carry out two unit root tests, the Augmented Dickey Fuller and the KPSS, in order to check the non-stationarity of the interest rates (Table 5). The Augmented Dickey Fuller test does not reject the null hypothesis of a unit root for the DTF at all significance levels. For the M3 this hypothesis is not rejected at $1 \%$ of significance. The test for the policy rate shows that the unit root hypothesis is not rejected at $1 \%$ and $5 \%{ }^{27}$. For the three interest rates, the KPSS test rejects the null hypothesis that each variable is stationary at all levels of significance. We can conclude from these results that the analyzed interest rates are $\mathrm{I}(1)$.

\footnotetext{
${ }^{27}$ For this test we take the minimum number of lags to get white-noise in the residuals. If the information criterion is used we do not get white-noise.
} 
TABLE 5

UNIT ROOT TESTS

\begin{tabular}{|c|c|c|c|c|c|c|c|c|}
\hline & \multicolumn{4}{|c|}{$\begin{array}{l}\text { Augmented Dickey-Fuller Test } \\
\text { Ho: variable has a unit root }\end{array}$} & \multicolumn{4}{|c|}{$\begin{array}{c}\text { KPSS Test } \\
\text { Ho: variable is stationary }\end{array}$} \\
\hline & \multirow[t]{2}{*}{$\begin{array}{l}\text { Test } \\
\text { statistic }\end{array}$} & \multicolumn{3}{|c|}{$\begin{array}{l}\text { Critical } \\
\text { Values }\end{array}$} & \multirow[t]{2}{*}{$\begin{array}{c}\text { Test } \\
\text { statistic }\end{array}$} & \multicolumn{3}{|c|}{$\begin{array}{c}\text { Critical } \\
\text { Values }\end{array}$} \\
\hline & & $1 \%$ & $5 \%$ & $10 \%$ & & $1 \%$ & $5 \%$ & $10 \%$ \\
\hline DTF (1) & -1.047 & -3.517 & -2.899 & -2.587 & 1.050 & 0.739 & 0.463 & 0.347 \\
\hline M3 interest rate & -3.407 & -3.510 & -2.896 & -2.585 & 1.096 & 0.739 & 0.463 & 0.347 \\
\hline Policy interest rate (3) & -2.774 & -3.511 & -2.896 & -2.586 & 0.928 & 0.739 & 0.463 & 0.347 \\
\hline
\end{tabular}

(1) 9 Lags used to get white noise residuals.

(2) 2 Lags used to get white noise residuals.

(3) 3 Lags used to get white noise residuals.

\section{B.2. Long Run Relationship}

The estimated long-run relationship between the policy rate and the deposit interest rates is shown in Table 6 . The unit root tests show that the residual of the equation for the DTF is stationary at $5 \%$ and $10 \%$, with the Engle-Yoo critical values. The residuals of the equation for the M3 interest rate do not present a unit root according to the Engle-Yoo (1987) critical values at all significance levels. These results imply that there is a cointegration between the deposit interest rates and the policy rate because these variables are $\mathrm{I}(1)$ and the residuals are $\mathrm{I}(0)$.

Dependent Variables

TABLE 6

LONG RUN EQUATIONS

\begin{tabular}{lcc}
\hline & DTF $(1)$ & M3 (2) \\
\hline Constant & 1.132 & -0.777980 \\
& $(0.345)$ & $(0.271)$ \\
Policy Rate & 1.003 & 0.822 \\
& $(0.037)$ & $(0.029)$ \\
Test Statistic* & -2.575 & -3.075 \\
\hline & Engle Yoo Critical Values** & \\
\hline $1 \%$ & $5 \%$ & $10 \%$ \\
2.60 & 1.95 & 1.61 \\
\hline
\end{tabular}

* Ho: existence of a unit root.

** Critical values for a sample of 100 observations and non-constant.

(1) 3 Lags used in the residual test to get white noise.

(2) Lags $=3$ used in the residual test to get white noise. 


\section{APPENDix C}

The description of the variables used in the econometric exercise is given in the following table.

TABLE 7

\section{DESCRIPTION OF THE VARIABLES}

\begin{tabular}{|c|c|c|c|c|}
\hline Variable & Definition & Sample & Frequency & Source \\
\hline$\Delta \mathrm{DTF}$ & $\begin{array}{l}\text { Difference of the } \\
\text { nominal 90-day deposit } \\
\text { interest rate }\end{array}$ & June 1999 August 2006 & Monthly & Banco de la República \\
\hline$\Delta \mathrm{M} 3(1)$ & $\begin{array}{l}\text { Difference of the } \\
\text { nominal average } \\
\text { deposit interest rate }\end{array}$ & June 1999 August 2006 & Monthly & Banco de la República \\
\hline$\triangle \mathrm{POLICY}$ & $\begin{array}{l}\text { Difference of the } \\
\text { nominal policy interest } \\
\text { rate "Subasta de } \\
\text { Expansión" }\end{array}$ & June 1999 August 2006 & Monthly & Banco de la República \\
\hline$\triangle$ DEPRECIATION & $\begin{array}{l}\text { Difference of the } \\
\text { nominal annualized } \\
\text { quarterly depreciation } \\
\text { (Domestic currency/ } \\
\text { Foreign currency) }\end{array}$ & June 1999 August 2006 & Monthly & Banco de la República \\
\hline$\triangle$ INFLATION & $\begin{array}{l}\text { Difference of the } \\
\text { consumer annual } \\
\text { inflation }\end{array}$ & June 1999 August 2006 & Monthly & DANE \\
\hline \multirow[t]{2}{*}{$\Delta \mathrm{IPI}$} & $\begin{array}{l}\text { Logarithmic difference } \\
\text { of the deseasonal } \\
\text { industrial production } \\
\text { index }\end{array}$ & June 1999 August 2006 & Monthly & DANE \\
\hline & & & & Authors \\
\hline$\triangle \mathrm{EMBI}$ & $\begin{array}{l}\text { Difference of the EMBI } \\
\text { Colombia }\end{array}$ & June 1999 August 2006 & Monthly & Bloomberg \\
\hline$\Delta$ LIBOR (2) & $\begin{array}{l}\text { Difference of the } \\
\text { nominal LIBOR in } \\
\text { dollars. }\end{array}$ & June 1999 August 2006 & Monthly & Datastream \\
\hline
\end{tabular}

(1) The M3 interest rate corresponds to the average of the interest rates for different types of deposits (saving accounts, 90-day CDs and 360-day CDs) weighted by their volume.

(2) LIBOR (London Interbank Offer Rate) is the interest rate for 3-month deposits in dollars. 